in the above extract, which is illustrated by some admirable plates of Tortoises by Mr. G.H.Ford; and such is also the excellent Catalogue of the Papilionida not long since brought out by Mr. G. R. Gray, which contains coloured figures of the new species described. We must therefore echo His Imperial Highness's expression of thankfulness to the Trustees for placing within our reach, at a moderate price, such a mass of valuable zoological literature.

In connexion with this subject we may also call attention to the vast additions which have been made to the zoological collections in the Museum in the course of the last twenty years, but especially since 1840, as shown in the following table, derived from the Parliamentary returns, as this more than anything will serve to show, not only the energy displayed in the conduct of the Department, but also the abundance of materials at the disposal of the authors of the different catalogues to enable them to render their works as perfect as possible :-

Additions made to the Zoological Collections in the British Museum during the years 1836 to 1855 inclusive.

\begin{tabular}{|c|c|c|c|c|}
\hline & Vertebrata. & $\begin{array}{l}\text { Insects and } \\
\text { Crustacea. }\end{array}$ & $\begin{array}{c}\text { Other } \\
\text { Invertebrata. }\end{array}$ & Total. \\
\hline 1836. & 302 & 1,755 & 248 & 2,305 \\
\hline 1837. & 1923 & 233 & 4,779 & 6,935 \\
\hline 1838. & 1088 & 1,807 & 803 & 3,698 \\
\hline 1839. & 1019 & 7,049 & 1,558 & 9,626 \\
\hline 1840. & 654 & 12,371 & 8,164 & 21,976 \\
\hline 1841. & 1936 & 3,744 & 11,345 & 16,238 \\
\hline 1842. & 2740 & 5,125 & 10,877 & 18,742 \\
\hline 1843. & 4503 & 10,221 & 6,150 & 20,874 \\
\hline 1844. & 3517 & 19,191 & 10,200 & 32,908 \\
\hline 1845. & 5842 & 8,868 & 2,688 & 17,398 \\
\hline 1846. & 4535 & 10,181 & 3,960 & 18,678 \\
\hline 1847. & 2396 & 6,337 & 5,524 & 14,266 \\
\hline 1848. & 2717 & 11,566 & 3,661 & 17,944 \\
\hline 1849. & 1608 & 5,011 & 3,559 & 10,178 \\
\hline 1850. & 2251 & 7,260 & 3,827 & 13,338 \\
\hline 1851. & 2889 & 9,438 & 8,415 & 20,742 \\
\hline 1852. & 2303 & 8,237 & 5,724 & 16,264 \\
\hline 1853. & $\mathbf{1} 979$ & 105,406 & 5,015 & 112,400 \\
\hline 1854. & 903 & 9,663 & 13,847 & 24,413 \\
\hline \multirow[t]{2}{*}{1855.} & 4865 & 15,173 & 4,340 & 24,378 \\
\hline & & & & 422,301 \\
\hline
\end{tabular}

Note on the Development of the Lampreys. By M. Schultze.

The author has examined the development of the ova of Petromyzon Planeri, which occurs commonly in a small brook near Berlin. The ova were artificially impregnated. The mature ova are white and 
opake; they possess a viscous, temporary outer envelope, and a finer delicate chorion (membrane coquillière of Vogt). The latter is finely punctured, and appears to be pierced by minute tubes, as in other fishes. The vitellus is furnished with an extremely delicate vitelline membrane. No micropyle could be discovered.

The segmentation of the vitellus commences six hours after impregnation. It implicates the whole of the yelk, and differs in this respect from that which occurs in other fishes, in which only a small portion of the vitellus (formative vitellus) undergoes this transformation. The segmentation of the vitellus in the Lampreys is exactly the same as in the Frogs, and the vitelline membrane furnishes very delicate envelopes for the segments, which are true cells.

The two first furrows are perpendicular, whilst the third is transverse, separating the egg into upper and lower portions. The segmentation goes on much more rapidly in the upper half, so that when the segmentation is complete (two days after fecundation), the cells contained in it are much smaller than those in the lower portion. During this period a large cavity is formed in the interior of the egg, but situated almost entirely in the upper part, which it dilates into a thin vesicle, whilst its bottom is formed by the large cells of the lower part of the egg. As in the eggs of the Frogs, this cavity disappears during the further development, and its purpose is not known.

The first changes which take place after segmentation consist in the increase of the upper part, which grows over the lower and covers it,-not equally on all parts of the circumference, but only on one side, by a margin in the form of a high ridge. At the side of the latter and beneath it, a hollow is formed in the lower part of the egg, corresponding to the anus in the eggs of the Frog. This is the entrance to a second cavity, the primitive alimentary cavity, which is developed during the diminution of the cavity of segmentation; it subsequently becomes the anus of the Lamprey, and is therefore the first portion of the fish to make its appearance. No trace of vibratile cilia is distinguishable on the surface of the egg, which does not exhibit any rotatory movement like that which distinguishes the eggs of the Frog. On the fifth day, dorsal ridges, like those of the Batrachia, make their appearance, and the dorsal furrow which is situated between them soon closes above; the extremity of the head now rises distinctly, whilst the anus constantly becomes smaller, but never disappears entirely. In the meantime the primitive alimentary cavity extends up to the extremity of the head of the embryo, whilst it disappears gradually in the neighbourhood of the anus, from the approximation of the large cells of the lower portion of the yelk, by which it was enclosed. In this way the primitive alimentary cavity, which never exhibits vibratile cilia in its interior, becomes the pharyngeal, and subsequently the branchial cavity. At this time also the chorda dorsalis and the heart make their appearance; the latter only makes sixteen pulsations in a minute. On the sides of the chorda dorsalis appear parts which become the lateral muscles (vertebral divisions of Vogt); above it are the commencements of the 
spinal cord and the cerebellum, the latter only forming a clavate inflation of the former, as in Amphioxus.

On the fourteenth day the young Lampreys, $1 \frac{1}{2}$ line in length, languid, white and opaque, quit the egg; they are incapable of rising from the bottom of the vessel. In the inflated extremity of the hinder part of the body are the large cells formed by the segmentation of the lower half of the vitellus; they are filled with the elements of the yelk, and do not entirely disappear for three or four weeks after exclusion. During this period the young fishes take no nourishment.

After leaving the egg, the branchial apertures are formed successively by wrinklings of the skin, which attain the number of seven on each side, and become constantly deeper until they reach the pharyngeal cavity. At the same time another wrinkle of the skin produces the mouth; and above the anterior extremity of the chorda dorsalis, between the skin and the cerebellum, there appears a spot of black pigment, which constitutes the eye. This is formed in the manner of the eye in the Invertebrata. Behind the eye, and near the brain, a large clear cell becomes filled with calcareous granules; this is the auditory vesicle, with the otolithes. The heart divides distinctly into ventricle and auricle, and the peripheric portion of the vascular system is developed. Behind the heart some large yellowish cells form the liver.

At the bottom of the branchial apertures the branchial filaments spring from the partitions; they are never furnished with vibratile cilia. The cartilaginous branchial arches commence their development from the chorda dorsalis, and passing beneath the skin of the partitions soon meet beneath, forming a branchial skeleton exactly like that of the mature Lamprey. Beneath the branchial cavity the branchial artery is produced, and between this and the skin a long oval gland, composed of small granulated cells, is formed. It is situated in a cavity with soft walls, which it fits exactly, and its surface is covered with vibratile cilia. The author regards it as a thymus gland, but it does not exist in the mature fish.

Round the mouth are formed the upper and lower lips, and two lateral flaps united with the upper lip. The young animal becomes more and more transparent; but in several parts of its body, especially over the artery and vein beneath the chorda dorsalis, cells of black pigment are deposited in a stellate form. Here also numerous adipose cells are developed, from which some small papillæ arise above the heart and liver ; these are directed towards the abdominal side, and oscillate freely; they also bear on their surface a longitudinal range of cilia. The author doubts whether they are the first rudiments of the kidneys or of the Wolffian body, as he subsequently saw the formation of a tortuous canal further back, but still above the liver, which presented no oscillations, and which perhaps would become the Wolffian body, discovered in other fishes not long since by $M$. Reichert. When the membranes of the intestine are developed, and the residue of the vitelline mass is consumed, a vibratile epithelium is seen in the posterior portion of the digestive tube. 
This is at four weeks after exclusion, and it is only then that the young Lampreys take some nourishment from the mud in which they delight to bury themselves. Some cartilages also now make their appearance at the anterior extremity of the chorda dorsalis; these are the foundations of the basilar cartilage of the cranium. The eyes are still deeply immersed in the skin, but the auditory vesicles are enlarged and the number of otolithes increased. A single olfactory organ, a small cavity covered with a vibratile epithelium, is situated in front of the brain, and receives a short, thick, olfactory nerve. It is remarkable, that four weeks after exclusion there was no trace of peripheric nerves, either in the head or body, although the spinal cord is very thick.-Comptes Rendus, Feb. 18, 1856, p. 336.

\section{ClaUSiLIA MORTILLETI.}

\section{To the Editors of the Annals of Natural History.}

Cheltenham, March 30, 1856.

Genthemen, - My attention was only very lately directed to a note from Herr Adolf Schmidt, of Aschersleben, in your 'Annals' for January last, mentioning the occurrence of Clausilia Mortilleti, Dumt., near Cheltenham.

In the autumn of last year I found a Clausilia in this neighbourhood, which I at first suspected might be Clausilia Rolphii, a species I have always hoped to find in this county. I sent three specimens to the British Museum, with the statement, that if not C. Rolphii, with which I was not acquainted, and the figure and description of which differ widely from each other and from the species itself in Turton's 'Manual,' it was probably Cl. Mortilleti, Dumt. I subsequently sent two examples of the same to Herr A. Schmidt, from whom I had previously received continental shells, with the note, that if it was not a very ventricose variety of Clausilia rugosa, it was probably Clausilia Mortilleti.

In this neighbourhood the species is extremely local. I found it in company with Azeca tridens, among nettles and long grass, in a damp and shaded locality, and did not procure more than a dozen examples altogether. It is not a very well marked species; but, in addition to structural points of difference, its "habit" is unlike that of C. rugosa.

I am, Gentlemen, yours obediently,

Charles Prentice.

On a supposed New Species of the Genus Equus. By M. I. Geoffroy Saint-Hilaire.

The Empress of the French has recently received as a present from the Viceroy of Egypt, and presented to the Menagerie of the Jardin des Plantes, two specimens of an Equine animal, which M. Geoffroy Saint-Hilaire considers to be a new species. It belongs to 


\section{$2 \mathrm{BHL}$ Biodiversity Heritage Library}

Schultze, Max Johann Sigismund. 1856. "Note on the development of the Lampreys." The Annals and magazine of natural history; zoology, botany, and geology 17, 443-446. https://doi.org/10.1080/00222935608697547.

View This Item Online: https://www.biodiversitylibrary.org/item/19391

DOI: https://doi.org/10.1080/00222935608697547

Permalink: https://www.biodiversitylibrary.org/partpdf/11347

\section{Holding Institution}

Natural History Museum Library, London

\section{Sponsored by}

Natural History Museum Library, London

\section{Copyright \& Reuse}

Copyright Status: Public domain. The BHL considers that this work is no longer under copyright protection.

This document was created from content at the Biodiversity Heritage Library, the world's largest open access digital library for biodiversity literature and archives. Visit BHL at https://www.biodiversitylibrary.org. 